\title{
Localisation of enteropathogens in paraffin embedded tissue by immunoperoxidase
}

\author{
KR PARSONS, AM WILSON, GA HALL, JC BRIDGER, N CHANTER, DJ REYNOLDS \\ From the Agricultural and Food Research Council, Institute for Research on Animal Diseases, Compton, \\ Newbury, Berks RG16 ONN
}

SUMMARY An indirect immunoperoxidase technique has been used to identify enteropathogens in formol-sublimate fixed paraffin embedded sections of calf intestine. Infections with bovine rotavirus, bovine coronavirus, Newbury agent SRV-1, and $\mathrm{K}^{\circ} 9^{+}$Escherichia coli have been detected in the intestines from experimentally infected and conventially reared diarrhoeic or normal calves. The ability to visualise enteropathogenic agents in histological sections resulted in the demonstration of virus infected cells at sites not previously shown to be infected using the immunofluorescence technique.

Diarrhoea frequently occurs in neonates and has been ascribed to a variety of infectious causes including viruses, bacteria, and protozoa. Excretion of an infectious agent in diarrhoeic faeces does not prove a causal association because enteropathogens may be excreted by normal animals. ${ }^{1}$ Direct localisation of an agent in association with characteristic lesions, however, provides a more definite diagnosis.

Most investigations have shown viral and bacterial antigens by immunofluorescence in cryostat sections of intestinal tissues. Collection of frozen material is inconvenient, however, and it dehydrates during storage; cryostat sections stained by immunofluorescence methods are of little value for detailed histological study. Fixed material has a number of advantages: it can be processed at a convenient time, thinner sections may be cut, it provides good preservation of cellular architecture, and it is excellent for detailed histological investigations.

This paper describes the application of immunoperoxidase staining to demonstrate the location and extent of bacterial and virus infections in paraffin embedded intestinal calf tissues so that infectious agents and characteristic lesions may be detected and studied in the same section.

\section{Material and methods}

In the indirect immunoperoxidase method antibody (primary antibody) is attached to the antigen under investigation, followed by an antiglobulin against

Accepted for publication 9 February 1984 immunoglobulins of the species providing the primary antibody. The antispecies antiglobulin is conjugated with horseradish peroxidase (peroxidase conjugated antibody).

The attached peroxidase is visualised by a histochemical reaction, usually employing Graham and Karnovsky's diaminobenzidine method. ${ }^{2}$

\section{INFECTED TISSUES AND THEIR FIXATION}

Infected tissues stained by the immunoperoxidase method were:

1 Monolayers of monkey kidney cells (MA 104) infected with the tissue culture adapted bovine rotavirus $^{3}$

2 Intestinal tissues from five gnotobiotic calves experimentally infected with rotavirus, 14 infected with Newbury agent, ${ }^{4}$ and two infected with Escherichia coli B41

3 Intestinal tissues from three conventionally reared calves infected with $E$ coli $\mathrm{B} 44$

4 Intestinal tissues from 14 conventionally reared calves which were excreting rotavirus, detected by enzyme linked immunosorbent assay (ELISA) ${ }^{5}$ of faeces

5 Intestinal tissues from eight conventionally reared diarrhoeic calves.

Fixatives tested using infected monolayers were acetone, ethanol, formol-calcium, and formolsublimate. Fixation was by immersion for $10 \mathrm{~min}$. Formol-sublimate was replaced by $80 \%$ ethanol for $10 \mathrm{~min}$ before mercuric chloride deposits were removed by immersion for $5 \mathrm{~min}$ in Gram's iodine, followed by $5 \mathrm{~min}$ in $0.5 \%$ sodium thiosulphate. 
Intestinal samples were removed under pentobarbitone sodium (Sagatal, May and Baker Ltd) anaesthesia ${ }^{4}$ and fixatives assessed using infected intestine were formol-sublimate and $12 \%$ neutral buffered formalin, the former being replaced after $24 \mathrm{~h}$ with $80 \%$ ethanol. Blocks were embedded in paraffin wax and sections cut at $5 \mu \mathrm{m}$.

\section{PREPARATION OF ANTISERA}

Rotavirus hyperimmune antiserum was raised by oral administration of $3.0 \mathrm{ml}$ of a cell-culture grown bovine rotavirus to a 15 day old gnotobiotic calf. This was followed by a second oral dose at 33 days and two intramuscular injections at 63 and 105 days with the same rotavirus, purified from MA-104 cells and emulsified with Freund's incomplete adjuvant; antiserum was obtained at 139 days of age. ${ }^{3}$

Coronavirus hyperimmune serum was prepared as described previously. ${ }^{\circ}$

Antiserum to the Newbury agent was raised by oral administration of $3.0 \mathrm{ml}$ of a bacteria free 0.45 $\mu \mathrm{m}$ faecal filtrate containing the isolate SRV $-1^{4}$ to a gnotobiotic calf at 22 and 42 days old. Antiserum was obtained at 57 days of age.

Antisera to live $E$ coli $\mathrm{B} 41$, grown on TGX medium, ${ }^{7}$ was prepared by the method of Sojka. ${ }^{8}$ Antisera to purified K99 adhesin" was prepared by subcutaneous injection of a rabbit with $200 \mu \mathrm{g}$ of antigen in $2 \mathrm{ml}$ of Freund's incomplete adjuvant. Four weeks later the rabbit was injected intravenously with $200 \mu \mathrm{g}$ of antigen and bled after a further 10 days.

IMMUNOPEROXIDASE STAINING PROCEDURE

Sections were dewaxed by successive immersion for $1 \mathrm{~min}$ in xylene, absolute alcohol, $90 \%$ alcohol, and $70 \%$ alcohol. Mercuric chloride deposit was removed as described for cell monolayers.

Inhibition of endogenous peroxidase was compared using $0.5 \% \mathrm{H}_{2} \mathrm{O}_{2}$ in methanol, $10 \% \mathrm{H}_{2} \mathrm{O}_{2}$ in methanol, $0.074 \% \mathrm{HCl}$ in ethanol, and periodic acid followed by sodium borohydride. ${ }^{10}$

To eliminate background staining sections were incubated with $20 \%$ non-immune serum for $10 \mathrm{~min}$. Non-immune serum was serum from uninfected rabbits or goats containing no cross reacting antibodies and corresponding to the animal species in which the peroxidase conjugated antibody was raised. Slides were then drained but not washed.

Antisera containing primary antibody diluted to $1 / 20,1 / 40,1 / 80$, and $1 / 160$ and peroxidase conjugated antisera diluted to $1 / 160,1 / 320,1 / 640$, and $1 / 1280$ in sterile phosphate buffered saline $\mathrm{pH} 7 \cdot 0$ (PBS) were tested at different temperatures and various incubation times.

Monolayers infected with rotavirus were

Parsons, Wilson, Hall, Bridger, Chanter, Reynolds $\stackrel{\varrho}{\overline{\bar{F}}}$ incubated with primary antiserum for 30 or $120 \mathrm{~min} \stackrel{0}{\rightleftharpoons}$ at room temperature followed by rabbit antibovine $\underline{\sigma}$ gamma globulin conjugated with peroxidase (RAB/PO, Nordic Immunological Laboratories Ltd) for 30 or $120 \mathrm{~min}$ at room temperature.

Sections of virus infected intestine were incubated 듬 with primary antiserum for 30 .min followed by $\frac{\bar{\rho}}{\vec{\sigma}}$ $\mathrm{RAB} / \mathrm{PO}$ for $30 \mathrm{~min}$ at room temperature, or with $\stackrel{\Phi}{\mathscr{\Phi}}$ antiserum for $120 \mathrm{~min}$ at room temperature or $18 \mathrm{~h} \%$ at $4^{\circ} \mathrm{C}$ followed by $\mathrm{RAB} / \mathrm{PO}$ for $120 \mathrm{~min}$ at room $\vec{\circ}$ temperature.

$E$ coli infected sections were incubated with anti- $\vec{\omega}$ sera to whole $E$ coli (B41) or K99 adhesin for 60 。 min at room temperature or $30 \mathrm{~min}$ at $37^{\circ} \mathrm{C}$ followed by $30 \mathrm{~min}$ exposure to $4^{\circ} \mathrm{C}$. This was followed by goat antirabbit peroxidase conjugate (Nordic $\left.{ }^{-}\right)$ Immunological Laboratories Ltd) for $30 \mathrm{~min}$ at room temperature.

Sections were washed with three changes of PBS음 for $5 \mathrm{~min}$ each before and after treatment with peroxidase conjugate.

The peroxidase was detected by incubation for $5 \stackrel{\frac{1}{2}}{\circ}$ min with freshly prepared $0.05 \% 3,33^{\prime}-\vec{\bullet}$ diaminobenzidine tetrahydrochloride (Koch-Light $\infty$ Laboratories Ltd), containing $0.01 \%$ hydrogen peroxide in PBS. Slides were washed for $10 \mathrm{~min}$ in running tap water to stop the reaction and counterstained briefly in Gills-3 haematoxylin (Lerner Laboratories), differentiated in acid alcohol, blued $\stackrel{0}{\circ}$ in tap water, dehydrated, and mounted in DPX (Gurr).

Specificity of viral antisera was demonstrated by use of each preimmune serum and antiserum on intestinal tissue of gnotobiotic calves infected with each of the viruses. Specificity of $E$ coli and K99 antisera was shown by staining tissues infected with $\mathrm{K} 88$ and an atypical $E$ coli."

\section{Results}

\section{STAINING CONDITIONS}

Acetone, formol-sublimate, formol-calcium, ando ethanol fixation were all excellent for immunoperoxidase staining of rotavirus in cell monolayers. O Formol-sublimate increased the contrast between N viral antigen and background by reducing non-N specific staining of tissue. Formol-sublimate fixed, ${ }_{\sigma}^{\omega}$ paraffin wax embedded tissues gave more intense specific staining of virus infected enterocytes than $12 \%$ neutral buffered formalin.

All methods examined inhibited endogenous peroxidase in erythrocytes, leucocytes, ando enterocytes satisfactorily, but there was variation in the degree of background staining. Treatment with hydrogen peroxide gave intense staining of viral antigen, but also dark non-specific background 
Table 1 Procedure for indirect immunoperoxidase staining

1 Dewax thoroughly with xylene and hydrate.

2 Remove mercuric chloride deposit with Gram's iodine and sodium thiosulphate.

3 Inhibit endogenous peroxidase with $0.01 \mathrm{M}$ periodic acid in distilled water for $10 \mathrm{~min}$ followed by $0.003 \mathrm{M}$ sodium borohydride in distilled water for $30 \mathrm{~min}$. Wash with three changes of PBS, 5 min each.

4 Treat with $20 \%$ non-immune serum for $10 \mathrm{~min}$; do not wash; drain serum from slides.

5 Incubate with optimally diluted primary antisera. Viral antisera for $18 \mathrm{~h}$ at $4^{\circ} \mathrm{C}$. E coli antisera for $60 \mathrm{~min}$ at room temperature. Wash with three changes of PBS, 5 min each.

6 Treat with optimally diluted peroxidase conjugate, $2 \mathrm{~h}$ on virus sections and $30 \mathrm{~min}$ on $E$ coli. Wash with three changes of PBS, 5 min each.

7 Incubate with freshly prepared $0.05 \%$ diaminobenzidine containing $0.01 \%$ hydrogen peroxide for $5 \mathrm{~min}$. Wash well in running tap water for 5 min.

8 Counterstain briefly in Gills-3 haematoxylin, blue dehydrate, clear, and mount in DPX (Gurr).

staining. Hydrochloric acid in ethanol reduced background staining, but virus infected enterocytes stained weakly. Best results were obtained by treatment with $0.01 \mathrm{M}$ periodic acid for $10 \mathrm{~min}$ followed by $30 \mathrm{~min}$ in $0.003 \mathrm{M}$ sodium borohydride; this gave pale background staining of leucocytes, erythrocytes, and mature enterocytes, and dark staining viral antigen in infected enterocytes. Non-specific background staining of tissue was reduced by incubation of sections with $20 \%$ non-immune serum before treatment with primary antisera.

Optimal dilutions of primary antisera determined by titration on positive sections were $1 / 80$ for rotavirus, $1 / 40$ for Newbury agent, 1/80 for coronavirus, and $1 / 160$ for $E$ coli. Optimal dilutions of peroxidase conjugated antibody were $1 / 320$ for rotavirus, Newbury agent, and $E$ coli and 1/640 for coronavirus.

Incubation of cell culture monolayers with rotavirus antiserum followed by $\mathrm{RAB} / \mathrm{PO}$ for $2 \mathrm{~h}$ each at room temperature gave dark background staining, but non-specific staining was reduced by incubation with antiserum and conjugate for only 30 min each. Specific staining of viral antigens in

Table 2 Demonstration of specificity of antisera using germ free calves mono-infected with enteropathogenic viruses

\begin{tabular}{|c|c|c|c|c|c|c|}
\hline \multirow[t]{3}{*}{ Infection } & \multicolumn{6}{|c|}{ Primary antiserum } \\
\hline & \multicolumn{2}{|c|}{ Rotavirus } & \multicolumn{2}{|c|}{ Coronavirus } & \multicolumn{2}{|c|}{ Newbury agent } \\
\hline & Pret & Post & Pre & Post & Pre & Post \\
\hline $\begin{array}{l}\text { Rotavirus (5)* } \\
\text { Coronavirus (1) } \\
\text { Newbury agent (3) }\end{array}$ & $\begin{array}{l}\overline{\text { NT }} \\
\text { NT }\end{array}$ & $\begin{array}{l}+ \\
- \\
-\end{array}$ & $\begin{array}{l}\text { NT } \\
- \\
\text { NT }\end{array}$ & $\begin{array}{l}- \\
+ \\
-\end{array}$ & $\begin{array}{l}\text { NT } \\
\text { NT } \\
-\end{array}$ & $\begin{array}{l}- \\
+\end{array}$ \\
\hline
\end{tabular}

*Number of calves shown in parentheses.

†Pre- or post-inoculation sera.

NT $=$ not tested. paraffin sections was obtained only after $18 \mathrm{~h}$ or more incubation at $4^{\circ} \mathrm{C}$ with primary antisera. Incubation for $2 \mathrm{~h}$ with $\mathrm{RAB} / \mathrm{PO}$ gave more intense specific staining but also caused higher non-specific background staining. Incubation of sections with $E$ coli antiserum for $30 \mathrm{~min}$ at $37^{\circ} \mathrm{C}$ followed by 30 min at $4^{\circ} \mathrm{C}$ gave results similar to those obtained with incubation for $60 \mathrm{~min}$ at room temperature. The optimal conditions and recommended procedure for indirect immunoperoxidase staining of formol-sublimate fixed paraffin-embedded tissues are given in Table 1.

\section{SPECIFICITY OF ANTISERA}

Preinoculation sera used at $1 / 40$ dilution gave no positive immunoperoxidase staining of antigen in infected tissues. Postinoculation sera showed specific staining for the virus under investigation (Table 2). Antisera to live $E$ coli $\mathrm{B} 41$ and K99 adhesin stained bacteria in tissue from B41 and B44 infected calves, but failed to stain $\mathrm{K}^{+} E$ coli in pig tissues and an atypical $E$ coli in calf tissues.

\section{LOCATION OF INFECTIONS}

The results of immunoperoxidase staining of calf tissues with antisera are shown in Table 3. Enterocytes infected with Newbury agent were detected in only $3 / 14$ calves, at 18 and $24 \mathrm{~h}$ after inoculation. Rotavirus infected enterocytes were demonstrated in two of three conventional calves infected with $E$ coli, confirming the previous finding of rotavirus in the faeces of these two calves by ELISA. Rotavirus infected enterocytes were seen in all 14 calves in which faecal excretion of rotavirus had been detected by ELISA. Small numbers of colonic enterocytes infected with coronavirus were found in three of these calves; coronavirus in the faeces of these calves had not been detected by ELISA. Of the eight conventionally reared diarrhoeic calves examined by immunoperoxidase for enteropathogens one was infected with rotavirus, two with coronavirus, four with rotavirus and coronavirus, and one with rotavirus and Newbury agent. Bacteria were found in association with the mucosa of the colon of the eight animals but were not $\mathrm{K}^{+} 9^{+} E$ coli .

Rotavirus infected enterocytes were detected by immunoperoxidase with a distribution similar to that described in studies using immunofluorescence ${ }^{12}-$ that is, on the surface of normal length villi. They were most numerous on the apical half of the villus, although infected cells were seen along its whole length (Fig. 1). Additionally, small numbers of rotavirus infected cells were detected in caecal crypts (Fig. 2).

Coronavirus infected cells were found with a distribution similar to that described in studies using 
Table 3 Immunoperoxidase staining in infected calf tissues

\begin{tabular}{|c|c|c|c|c|c|c|c|}
\hline \multicolumn{2}{|c|}{ Calves } & \multirow[t]{2}{*}{ Infection } & \multicolumn{5}{|l|}{ Antiserum } \\
\hline No & Type & & Rotavirus & Coronavirus & Newbury agent & $E$ coli $B 41$ & K99 adhesin \\
\hline $\begin{array}{r}2 \\
5 \\
14 \\
2 \\
3 \\
14 \\
8\end{array}$ & $\begin{array}{l}\text { Gnotobiotic } \\
\text { Gnotobiotic } \\
\text { Gnotobiotic } \\
\text { Gnotobiotic } \\
\text { Conventional } \\
\text { Conventional } \\
\text { Conventional }\end{array}$ & $\begin{array}{l}\text { None } \\
\text { Rotavirus } \\
\text { Newbury agent } \\
E \text { coli } \text { B41 } \\
E \text { coli B44 } \\
\text { Rotavirus } \\
\text { Unknown }\end{array}$ & $\begin{array}{l}0 \\
5^{*} \\
0 \\
0 \\
2 \\
14 \\
6\end{array}$ & $\begin{array}{l}0 \\
0 \\
0 \\
0 \\
0 \\
3 \\
6\end{array}$ & $\begin{array}{l}0 \\
0 \\
3 \\
0 \\
0 \\
0 \\
1 .\end{array}$ & $\begin{array}{l}\text { NT } \\
\text { NT } \\
\text { NT } \\
2 \\
3 \\
\text { NT } \\
0\end{array}$ & $\begin{array}{l}\text { NT } \\
\text { NT } \\
\text { NT } \\
2 \\
3 \\
\text { NT } \\
0\end{array}$ \\
\hline
\end{tabular}

*Number of animals positive.

$\mathrm{NT}=$ not tested as no adherent bacteria observed.

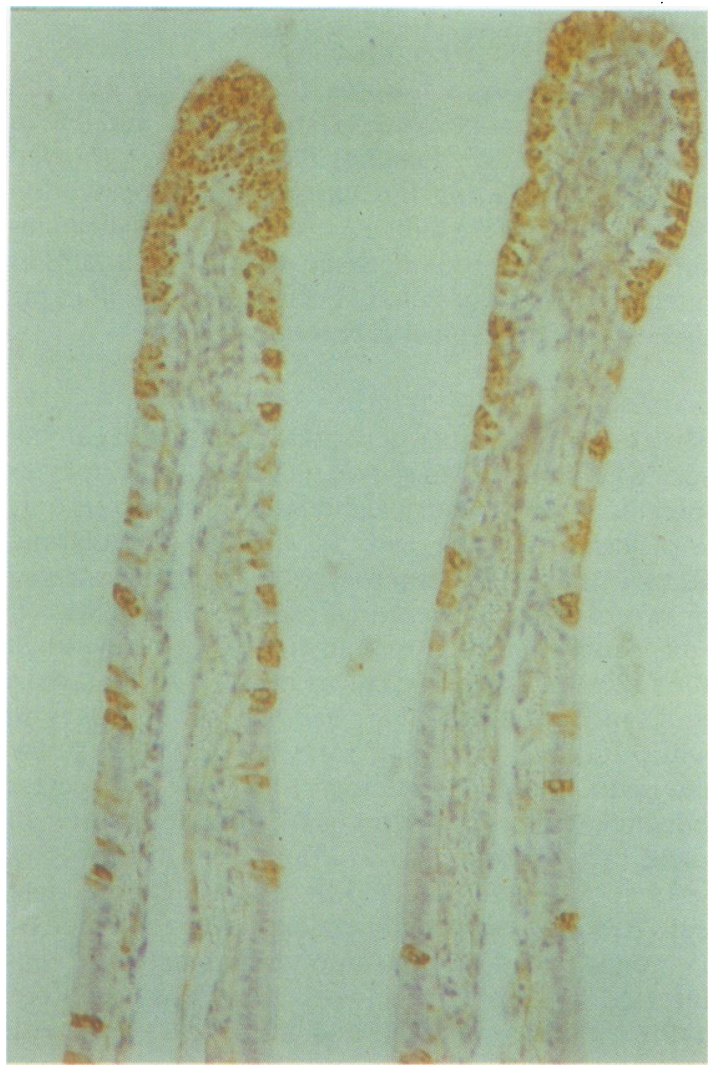

Fig. 1 Rotavirus infected enterocytes distributed along the whole length of the villus of the mid-ileum. Original magnification $\times 200$.

immunofluorescence ${ }^{13}$ - that is, on the surface of ileal villi, caecum, and colon and in caecal and colonic crypts (Fig. 3). Additionally, small numbers of crypt cells were seen to be infected in the ileum.

Newbury agent was found to infect enterocytes primarily near the base of the villi (Fig. 4) in the upper small intestine. In experimentally infected calves adherent $E$ coli $\mathrm{B} 41$ and B44 were demonstrated using B41 antiserum and shown to possess the K99 adhesin (Fig. 5).

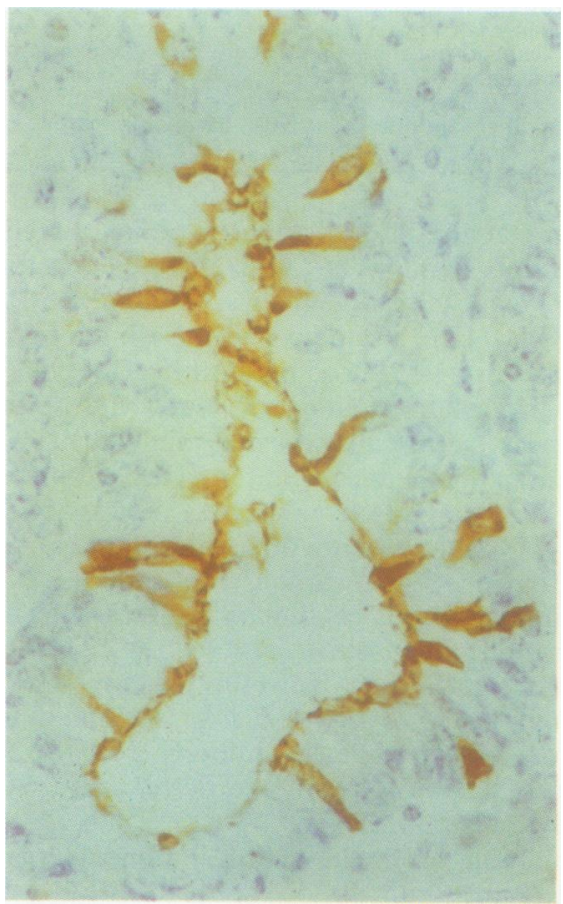

Fig. 2 Rotavirus infected crypt enterocytes of the caecum. Original magnification $\times 500$.

\section{Discussion}

The ease with which antigens may be detected in $N$ fixed tissue by the immunoperoxidase system is dependent on the accessibility of the antigen to the primary antibody. Antigen availability is affected by $\omega$ the length of exposure fixative, ${ }^{14}$ choice of fixative,,$^{15}$ and presumably by the thickness of tissue. In this study viral antigen in monolayer cell cultures was stained satisfactorily by a short incubation with primary antisera, probably because of the short fixation time. Overnight incubation of paraffin sections with primary antiserum was necessary to stain virus infected tissues, presumably due to slower penetration_of primary antibody into tissue sections, 


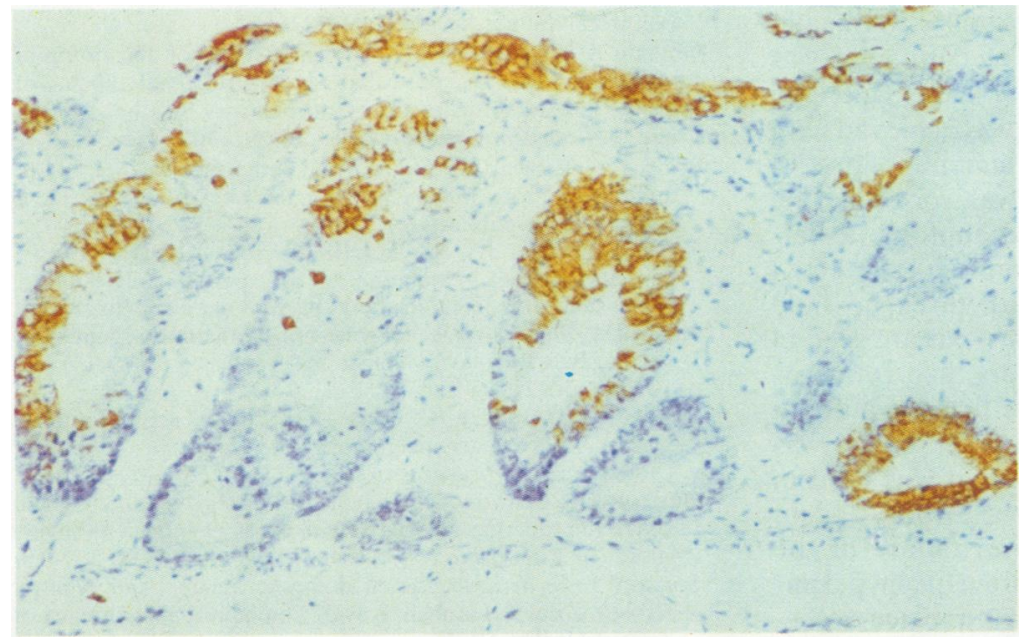

Fig. 3 Severe infection of surface and crypt enterocytes of the colon with coronavirus. Original magnification $\times 200$.

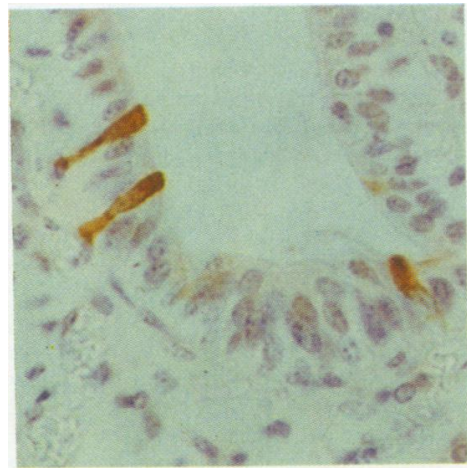

Fig. 4 Enterocytes at the base of a villus of the mid-ileum infected with Newbury agent SRV-1. Original magnification $\times 500$.

which are much thicker than monolayers, and the decreased immunoreactivity of viral antigens after prolonged fixation. Demonstration of rotavirus antigen in paraffin sections of Zenker fixed ileum ${ }^{16}$ has been reported, but the incubation times used were not.

Fixation is an important factor in the demonstration of antigens in paraffin embedded tissues by the immunoperoxidase technique. ${ }^{15}$ Formalin is used for routine fixation in most laboratories, but improved immunoperoxidase staining with mercury based fixatives has been reported. ${ }^{15}$ Our observations confirmed these findings: formol-sublimate fixation reduced non-specific background staining of tissues and produced more intense staining of viral antigens in enterocytes. Viral antigens in paraffin embedded tissues have been detected by the immunoperoxidase method following Zenker fixation $^{16}$ (rotavirus), fixation in cold $98 \%$ alcohol ${ }^{17}$

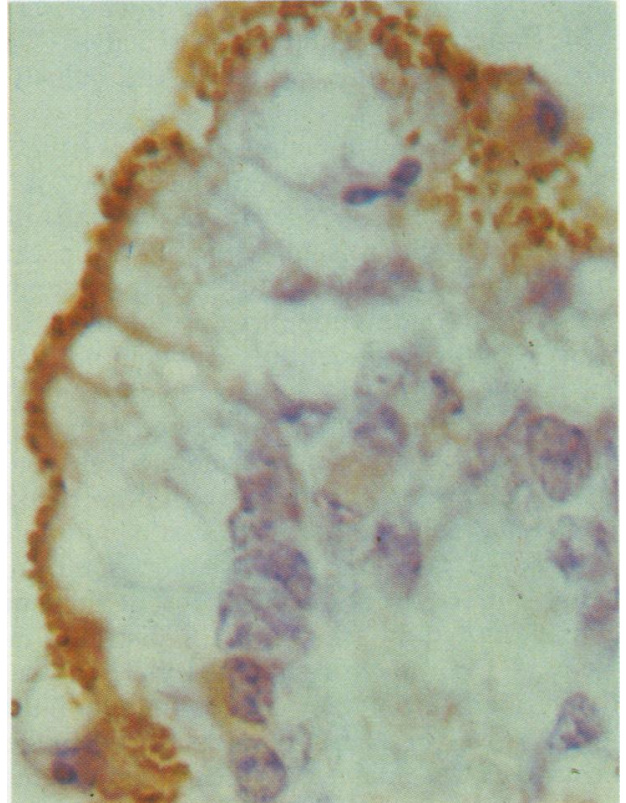

Fig. 5 Escherichia coli $\mathrm{B} 41$ stained for the $\mathrm{K}^{\circ} 9^{+}$adhesin, attached to the villus enterocytes of proximal ileum. Original magnification $\times 800$.

(bovine virus diarrhoea virus), and formalin ${ }^{18} 19$ (hepatitis B virus, ${ }^{20}$ herpes simplex virus).

Endogenous peroxidase was sufficiently inhibited by all methods examined, but non-specific attachment of peroxidase conjugate caused dark background staining which interfered with the interpretation of results. Background staining was affected by the fixative, method of inhibiting endogenous peroxidase, and treatment of sections with nonimmune serum, but could be completely eliminated 
only by high dilution of the peroxidase conjugate. Thus where an optimal dilution of conjugate was used, strong positive staining of virus infected enterocytes and adherent bacteria was achieved with minimal non-specific background staining.

The specificity of the antisera was confirmed by use of tissues from mono-infected gnotobiotic calves. Poor results were obtained from calves infected with Newbury agent and there are three possible reasons for this. Newbury agent particles are seen in intestinal contents in lower numbers than rotavirus and coronavirus, ${ }^{21}$ so it is probable that the amount of antigen available for detection in enterocytes was low. Secondly, convalescent antiserum was used in the immunoperoxidase test for Newbury agent which was likely to be of low titre; failure of the virus to grow in tissue culture prevents hyperimmunisation. Thirdly, Newbury agent calves were killed at intervals of 0.5 to 10 days after inoculation so that not all were expected to be infected at the time of slaughter. Presumably the calves which stained positively were those at the height of infection.

Detection of mixed infections in tissues from naturally infected calves showed the value of the method in investigating farm cases, and identification of coronavirus infection in three calves with faeces negative by ELISA suggested a superior sensitivity by the immunoperoxidase method.

It can be difficult to identify, with confidence, the precise position of small numbers of cells stained by immunofluorescence, but virus infected cells stained by immunoperoxidase can be examined in sections where the cellular architecture is well preserved and single infected cells can be identified as an integral part of the sections and distinguished from exfoliated, infected enterocytes present in luminal contents. This study has shown a distribution of rotavirus and coronavirus infected cells similar to that described in studies using immunofluorescence. ${ }^{1213}$ However, small numbers of cells infected with rotavirus were detected in the colonic mucosa, small numbers of crypt cells infected with coronavirus were detected in the ileum, and a few cells infected with Newbury agent were detected at the base of jejunal villi; none of these sites has been shown previously to be infected in calves using the immunofluorescence technique. These observations and those of Newbury agent infection illustrate the value of antigen detection in good histological sections.

We thank Mr PF Dennis for preparation of the histological sections and $\mathrm{Mr}$ IMH Jebbett for the photographs.

\section{References}

' McNulty MS, Logan EF. Longitudinal survey of rotavirus infec- tion in calves. Vet Rec 1983;113:333-5.

${ }^{2}$ Graham KC, Karnovsky MJ. The early stages of absorption of injected horseradish peroxidase in the proximal tubules of mouse kidney: ultrastructural cytochemistry by a new technique. J Histochem Cytochem 1966; 14:291-302.

${ }^{3}$ Bridger JC, Brown JF. Antigenic and pathogenic relationship of three bovine rotaviruses and a porcine rotavirus. J Gen Virol (submitted for publication).

${ }^{4}$ Hall GA, Bridger JC, Brooker BE, Parsons KR, Ormerod E. The pathology of gnotobiotic calves experimentally infected $\mathbb{D}$ with a calicivirus-like (Newbury) agent. Vet Pathol (in press).

s Ellens DJ, DeLeeuw PW. Enzyme-linked immunosorbent assay es for diagnosis of rotavirus infections in calves. J Clin Microbiol $\vec{\circ}$ 1977;6:530-2.

- Reynolds DJ, Bridger JC, Chasey D, Scott AC. Evaluation of $\overrightarrow{\vec{\omega}}$ ELISA and electronmicroscopy for detection of bovine $\omega$ coronavirus and rotavirus in faeces. Vet $\operatorname{Rec}$ (in press)

' Burrows MR, Sellwood R, Gibbons RA. Haemagglutinating and adhesive properties associated with the $K 99$ antigen of bovine ${ }^{\omega}$ strains of Escherichia coli. J Gen Microbiol 1976;96:269-75. ه

"Sojka WJ. Escherichia coli in domestic animals and poultry. Review series 7. Farnham Royal: Commonwealth Bureaux of $\frac{A}{G}$ Animal Health, 1965.

- Chanter N. Structural and functional differences of the anionic 윽 and cationic antigens in $\mathrm{K} 99$ extracts of Escherichia coli B41.J Gen Microbiol 1982;128:1585-9.

"' Heyderman E, Neville AM. A shorter immunoperoxidase technique for the demonstration of carcinoembryonic antigen and $(\mathbb{D}$ other cell products. J Clin Pathol 1977;30:138-40.

" Chanter N, Morgan JH, Bridger JC, Hall GA, Reynolds DJ. The reproduction of dysentery in gnotobiotic calves by atypical ${ }^{+}$ Escherichia coli. Vet Rec 1984;114:71.

12 Mebus CA, Newman LE. Scanning electron, light and immunofluorescent microscopy of intestine of gnotobiotic calf infected with reovirus-like agent. Am $J$ Vet Res $\overline{0}$ 1977;38:553-8.

${ }^{13}$ Bridger JC, Woode GN, Meyling A. Isolation of coronaviruses from neonatal calf diarrhoea in Great Britain and Denmark. Veterinary Microbiology 1978;3:101-13.

${ }_{14}$ Mepham BL, Frater W, Mitchell BS. The use of proteolytic 3 enzymes to improve immunoglobulin staining by the PAP technique. Histochem J 1979;11:345-58.

is Piris J, Thomas ND. A quantitative study of the influence of fixation on immunoperoxidase staining of rectal mucosalo plasma cells. J Clin Pathol 1980;33:361-4.

${ }^{16}$ Graham DY, Estes MK. Comparison of methods for immunocytochemical detection of rotavirus infections. Infect Immun. 1979;26:686-9.

"Ohmann HB, Jensen MH, Sørensen KJ, Dalsgaard K. Demonstration of bovine viral diarrhoea virus antigen in cryostat- and $O$ paraffin-sections of bovine tissues by the immunoperoxidase technique. Acta Pathol Microbiol Scand 1981;89:281-5.

${ }^{i x}$ Huang $\mathrm{S}-\mathrm{N}$. Immunohistochemical demonstration of hepatitis $\mathrm{B}$ 음 core and surface antigens in paraffin sections. Lab Invest 1975;33:88-95.

${ }^{14}$ Burns J. Immunoperoxidase localisation of hepatitis B antigen (HB) in formalin-paraffin processed liver tissue. Histochemistry 1975;44:133-5.

${ }^{20}$ Merkel KHH, Zimmer M. Herpes simplex encephalitis. A mod- $\omega$ ified indirect immunoperoxidase technique for rapid diagnosis< in paraffin-embedded tissue. Arch Pathol Lab Med읃 1981; 105:351-2.

${ }^{21}$ Bridger JC, Hall GA, Brown JF. Characterization of a calici-like virus (Newbury agent) found in association with astrovirus in bovine diarrhoea. Infect Immun 1984 (in press).

Requests for reprints to: Mr KR Parsons, Agricultural and Food Research Council, Institute for Research on Animal Diseases, Compton, Newbury, Berks RG16 0NN. England. 